\title{
Nutritional status of preschool children in informal settlement areas near Bloemfontein, South Africa
}

\author{
A Dannhauser ${ }^{1, *}$, CJ Bester ${ }^{2}$, G Joubert $^{2}$, PN Badenhorst ${ }^{3}$, M Slabber $^{1}$, AM Badenhorst ${ }^{1}$, \\ E Du Toit ${ }^{1}, \mathrm{HC}$ Barnard ${ }^{4}, \mathrm{P}$ Botha $^{5}$ and L Nogabe ${ }^{6}$ \\ 'Department of Human Nutrition, University of the Orange Free State, PO Box 330, Bloemfontein 9300, \\ South Africa: ${ }^{2}$ Department of Biostatistics, University of the Orange Free State, PO Box 330, Bloemfontein \\ 9300, South Africa: ${ }^{3}$ Department of Haematology and Cell Biology, University of the Orange Free State, \\ PO Box 330, Bloemfontein 9300, South Africa: ${ }^{4}$ Department of Chemical Pathology, University of the \\ Orange Free State, PO Box 330, Bloemfontein 9300, South Africa: ${ }^{5}$ Department of Medical Microbiology, \\ University of the Orange Free State, PO Box 330, Bloemfontein 9300, South Africa: ${ }^{6}$ Mangaung University \\ Community Partnership Programme P.O. Box 23160, Kagisanong, 9323
}

Submitted 21 September 1999: Accepted 7 January 2000

\begin{abstract}
Objective: To determine the nutritional status and household resources of preschool children.

Design: A cross-sectional survey.

Setting: Two informal settlement areas, Joe Slovo (JS) and JB Mafora (JBM) in Mangaung, near Bloemfontein, South Africa.

Subjects: Preschool children ( $<72$ months) of a randomly selected sample of households in JS (experimental) $(n=162)$ and JBM (control) $(n=186)$ were included. Standard methods were used to obtain household and care-giver particulars, weight and height measurements, blood and stool samples, and 24-hour dietary recalls.

Results: Breast-feeding and dietary intake in the two areas were nearly similar; breastfeeding was continued for 12 months and longer. Although the children's total protein intake was sufficient, their energy intake was low. A low median intake of micronutrients prevailed, including iron, zinc, calcium, niacin, riboflavin, thiamine and vitamins $\mathrm{C}, \mathrm{B}_{6}, \mathrm{~A}$ and $\mathrm{D}$. The prevalence of being underweight (JS $=19.8 \%$; JBM = $18.8 \%)$, stunted $(\mathrm{JS}=29 \% ; \mathrm{JBM}=21.5 \%)$ and wasted $(\mathrm{JS}=6.5 \% ; \mathrm{JBM}=3.7 \%$ ) were fairly similar in both areas, as well as the prevalence of marginal vitamin A deficiency, anaemia, iron deficiency and parasite infestations. No significant associations could be found between household and nutritional status indicators, probably due to the small number of well-nourished children and the generally poor household situation of the participants.

Conclusions: The generally poor nutritional status and environmental conditions emphasize the urgency of intervention for these children.
\end{abstract}

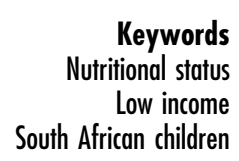

Globally it is estimated that among preschool-age children in developing countries 183 million are underweight, 226 million are stunted and 67 million wasted $^{1}$. These estimates highlight the magnitude of the different forms of malnutrition and increase awareness of the critical importance to overcome the problem.

In South Africa urbanization is occurring at an exceptionally high rate and informal (shack) settlement areas (shanty towns) have increased on the outskirts of cities and towns. The extent of undernutrition in the informal settlement areas is high ${ }^{2,3}$, while national studies have indicated a similar overall prevalence of undernutrition amongst preschool-age children in South Africa ${ }^{4,5}$. The implications of undernutrition are far-reaching. Apart from the cost involved in treating these children, early chronic malnutrition limits the intellectual and biological abilities with long-term effects in adulthood ${ }^{1,6}$. Thus it is important to overcome the problem in South Africa.

The planning and implementation of effective nutrition intervention programmes should be based on the specific needs of individuals or communities ${ }^{7}$. Nutrition education based on individual needs is more important and in the long term more effective than the distribution of free food. The 'triple A' approach describes the steps in the process of assessing nutrition-related problems, analysing their causes and taking action on analysis ${ }^{8}$. While nutritional assessment is regarded as the first step in the process of identifying nutrition-related problems, appropriate indicators are required to identify the nature and extent of the problems ${ }^{8,9}$. Nutritional assessments include different 
methods and combinations of methods ${ }^{9,10}$. Due to the problems associated with all methods of nutritional assessment, adherence to proper techniques and proper training of fieldworkers is essential to ensure accurate and precise measurements ${ }^{10,11}$. Therefore, to confirm the existence of a nutritional deficiency it is recommended that various measurements of nutritional status be used in conjunction and interpreted with caution.

Furthermore, the causes of malnutrition are seen as deeply rooted in environmental factors, such as poverty and lack of education ${ }^{6,12}$. These factors are also described as immediate, underlying and basic causes ${ }^{8}$. In any attempt to improve nutritional status it is therefore important to assess the relationship between environmental factors and nutritional status indicators.

With the view of implementing a nutrition education intervention programme in informal settlement areas in Mangaung in the greater Bloemfontein area, the present baseline study was considered essential. The aim of this study was to assess the nutritional status (dietary intake, anthropometric and biochemical profiles, and parasite infestations) and household resources (household and care-giver particulars) of the children, in an attempt to identify specific issues which should be addressed in an intervention programme.

\section{Methods}

\section{Subjects}

In cooperation with members of the Mangaung community, two more-or-less similar informal housing settlement areas in Mangaung were selected for inclusion in the study: Joe Slovo (JS) as the experimental area and JB Mafora (JBM) as the control area. JS was to serve as the experimental area in which the nutrition intervention programme would be implemented for 3 years, starting in 1998, after completion of the baseline study. JBM was to serve as the control area to evaluate the impact of the intervention programme.

By means of aerial photographs of the two areas, systematic sampling of 50 random starting points were identified and numbered. At each starting point the trained fieldworkers (community members of the specific area) had to follow a set procedure to select the first three households with preschool children and a care-giver. Care-giver shall for the purpose of this study refer to the person in whose care the child is for most of the time, and can be the mother, father, grandmother, grandfather, aunt, uncle, neighbour or sister older than 16 years. Preschool children shall, for the purpose of this study, refer to children younger than 72 months. Each afternoon the fieldworkers (living in JS and JBM) identified the next starting points in the two areas, as well as the three households at each starting point to be included in the study. The care-giver(s) of a household had to bring all the preschool children in the household to a specific nearby clinic the next morning. If the subjects did not turn up the fieldworkers went back to the specific houses and accompanied them to the clinic.

The final sample consisted of 141 households and a total of 162 children younger than 72 months in JS, and 145 households with a total of 186 children in JBM.

\section{Housebold resources}

Standardized questionnaires were used to obtain the household resource and care-giver information from the care-giver during a personal interview at the clinic. Household resources include, for example, structure of the house, room density, availability of electricity and tap water, fuel for food preparation, type of toilet and means of transport. Interviews were conducted by final-year dietetic students. Interpreters were used where the respondent could not understand Afrikaans or English.

\section{Dietary intake}

A 24-hour recall was completed for each child during a personal interview with the care-giver of the child. The 24-hour recalls were conducted by two trained dietetic students at each clinic. They were standardized against each other to ensure that the information was interpreted in the same way. Food models were used to estimate the portion sizes accurately in grams. Examples of cups and spoons used by the study population were collected during the pilot study and measured in millilitres. These utensils were used to estimate portion sizes in millilitres. Portion sizes were then converted to grams using the Food Quantities Manual ${ }^{13}$. The dietary data was analysed, using the MRC Food Composition Tables (1991) ${ }^{14}$. The median nutrient intakes were compared to the recommended dietary allowances (RDA) of the United States ${ }^{15}$. Essential fatty acid intakes of the children were evaluated according to the Canadian recommendation ${ }^{16}$. The frequency of food intake per day was calculated from the 24-hour recall data.

\section{Antbropometric measurements}

Standard anthropometric methods were used by two trained dietetic students at each clinic $^{10,11}$. Trained personnel from the Department of Health assisted with measuring and handling of the children. Weight was measured by using a Masscot scale, accurate to the nearest $0.1 \mathrm{~kg}$. The children were weighed barefoot and clothed in light indoor clothing. Small children were held by an adult while both were weighed; the mother was then weighed alone and the child's weight was calculated by subtracting the mother's weight from the total weight. Height was measured to the nearest $0.1 \mathrm{~cm}$, by means of an anthropometer with a vertical scale of $2 \mathrm{~m}$ and a sliding head piece, while the child stood barefoot on the platform with the heels touching the anthropometer. The crown to heel length of children younger than 24 months, or those who could not stand on their own, were measured on a 
paediatric measuring board, to the nearest $0.1 \mathrm{~cm}$. The mid upper arm circumference (MUAC) of children 1 year and older was measured with a light steel measuring tape, to the nearest $0.1 \mathrm{~cm}$. Triceps skinfold (TS) of children 2 years and older was measured by means of a Harpenden skinfold caliper with a standardized pressure of $10 \mathrm{~g} \mathrm{~mm}^{-2}$, to the nearest $0.2 \mathrm{~mm}$. All measurements were taken three times and averages calculated. Upper arm muscle area (UAMA) and upper arm fat area (UAFA) were calculated from MUAC and TS values using standard formulae for children ${ }^{11}$. Head circumference (HC) of children 2 years and younger was measured with a light steel measuring tape to the nearest $0.1 \mathrm{~cm}^{10,17}$.

Values of the National Centre for Health Statistics (NCHS $)^{18}$ were used as reference standards for the interpretation of anthropometric measurements. The $-2 \mathrm{SD}$ refers to the Z-score cut-off which is two standard deviations below the reference median and compares with the values of the third percentile ${ }^{18,19}$. Weight for age (W/A), height for age (H/A) and weight for height $(\mathrm{W} / \mathrm{H})$ were classified as moderately depleted $(<-2 \mathrm{SD})$, mildly depleted $(-2$ to $<-1 \mathrm{SD})$, normal $( \pm 1 \mathrm{SD})^{6,12}$ and excessive $(>2 S D)^{6}$. For the purpose of this study the slightly above normal category $(>1$ to $2 \mathrm{SD})$ were classified as normal. Values below the fifth percentile of the NCHS were used to classify MUAC, TS, UAMA, UAFA and $\mathrm{HC}$ as $\operatorname{low}^{11}$. For the purpose of this study the slightly below normal $(5$ to $<15)$ category was also calculated for MUAC, TS, UAMA and UAFA ${ }^{11}$; the normal (15-85) and above normal $(85$ to $<95)$ categories were classified together as normal $(15$ to $<95)$ for MUAC, TS and UAMA. For UAFA the normal $(15$ to $<75$ ) and above normal ( 75 to $<85$ ) categories $^{11}$ were classified together as the normal category $(15$ to $<85)$. Values $\geqslant 95$ were classified as excessive for MUAC, TS and UAMA, while values $\geqslant 85$ was classified as excessive for $\mathrm{UAFA}^{11}$.

\section{Laboratory tests}

Blood samples $(5 \mathrm{ml})$ were taken according to standard methods by physicians of the Department of Paediatrics and Child Health, University of the Orange Free State and analysed in the Departments of Chemical Pathology and Haematology. Plasma vitamin A was determined by high pressure liquid chromatography (HPLC). The method of Nierenberg and $\mathrm{Nann}^{20}$ was used to extract and determine vitamin A status. Vitamin A status was classified on the basis of plasma vitamin A concentration, according to the reference criteria suggested by the World Health Organization (WHO) ${ }^{21}$ and as used in the South African Vitamin A Consultative Group (SAVACG) study ${ }^{5}$ as follows: vitamin A deficiency: $<10 \mu \mathrm{g} \mathrm{dl}^{-1}$; low (marginal vitamin A status): 10-19.9; adequate status: 20-29.9; normal/well nourished: $\geqslant 30$; high: $\geqslant 50 \mu \mathrm{g} \mathrm{dl}^{-1}$.

Full blood counts, including haemoglobin ( $\mathrm{Hb})$, haematocrit and mean corpuscular volume (MCV) were determined on a Technicon H1 blood cell analyser. Plasma ferritin concentration was determined by fluorescent microparticle enzyme immunoassay using an Abott IMX analyser. Plasma transferrin was determined by the Behring Nephelometric method (Behring AG, Marburg, Germany). Plasma albumin was determined by a discrete Technicon 'Dax' analyser.

Due to a lack of enough blood plasma iron could not be determined and the transferrin saturation and iron-binding capacity could therefore not be calculated. A clear distinction between iron deficiency and iron depletion could thus not be made. The prevalence of anaemia, iron depletion and iron deficiency anaemia were determined by haemoglobin and plasma ferritin concentrations, as well as MCV. Criteria applied to assess iron status in the SAVACG study ${ }^{5}$ were used to describe anaemia and iron status, as follows: anaemia: $\mathrm{Hb}<11 \mathrm{~g} \mathrm{dl}^{-1}$; iron depletion: ferritin $<12 \mu \mathrm{gl}^{-1}$; iron deficiency anaemia: $\mathrm{Hb}<11 \mathrm{~g} \mathrm{dl}^{-1}+$ ferritin $<12 \mu \mathrm{gl}^{-1}+\mathrm{MCV}$ in children $0-2$ years $<73 \mathrm{fl}$, $3-4$ years $<75 \mathrm{fl}, 5$ years $<76 \mathrm{fl}$. Age-specific cut-off points for children of 72 months and younger ${ }^{22}$ were also used.

Stool samples from the children were handed in at the clinic in $40 \mathrm{ml}$ plastic containers issued to the care-givers on the previous day. The stool samples were analysed in the Department of Medical Microbiology. A wet preparation in saline was examined specifically for trophozoites using the $40 \times$ objective $\mathrm{o}^{23}$. The formalin-ether method was used to concentrate parasites in the sediment $^{23}$. A Lugol iodine preparation of sediment was examined for cysts ${ }^{23}$.

\section{Statistical analysis}

The Epi-info computer program ${ }^{24}$ was used to analyse the weight and height data. All other analyses were done using SAS ${ }^{25}$. Frequencies and percentages were used to describe categorical data, and means, standard deviations and medians to describe continuous data. Nutritional status was categorized as undernourished $(\mathrm{W} / \mathrm{H}<-2 \mathrm{SD}$ or $\mathrm{H} / \mathrm{A}<-2 \mathrm{SD}$ ); well nourished (W/A $>0 \mathrm{SD}$ and H/A $>0 \mathrm{SD}$ ); and in between (the remainder). Contingency tables were used to determine the association between environmental factors and nutritional status. Survival analysis was used to calculate the percentage of children still breast-fed at the different ages.

Ethical approval for this study was given by the Ethical Committee of the Faculty of Health Sciences of the University of the Orange Free State (ETOVS number 173/96).

\section{Results}

The results are presented for the two areas. Of the sample of children younger than 72 months in JS, 76 were male (46.9\% of 162), while in JBM 95 (51.1\% of 186) of the children were male. The median ages were 3.1 years in both areas ( $\mathrm{JS}=3.0 \pm 1.5 ; \mathrm{JBM}=2.9 \pm 1.6$ ). 


\section{Housebold resources}

The results of the household resources, food buying practices and reasons thereof are not tabulated. The houses in both areas were mostly of corrugated iron (JS $=73.8 \%$; $\mathrm{JBM}=81.4 \%$ ) and consisted mainly of one room in JBM (94.5\%) and of two (38.3\%) or one (36.2\%) rooms in JS. Room density was relatively high with three or more people ( $\max .15)$ sleeping in each room $(\mathrm{JS}=83 \%$; JBM $=$ 96.6\%). Most of the households had no electricity (JS= $97.2 \% ; \mathrm{JBM}=97.2 \%)$. In JS tap water was mainly available from a tap on the premises (53.2\%) and in JBM from a tap in the neighbourhood (90.3\%). Paraffin (in Primus stoves) was the main fuel used for food preparation (JS $=87.9 \%$; $\mathrm{JBM}=86.2 \%)$. Taxis were the predominant mode of transport ( $\mathrm{JS}=93.6 \%$; $\mathrm{JM}=95.2 \%$ ).

More of the children in JBM (75.8\%) than in JS (55.6\%) were cared for by their mothers, while more mothers were formally employed in JS (JS $=34 \% ; \mathrm{JBM}=18.3 \%$ ). The majority of fathers were formally employed (JS $=62.4 \%$; $\mathrm{JBM}=72.8 \%$ ), lived in the same house as the family (JS= $58.1 \% ; \mathrm{JBM}=62.9 \%)$ and supported the family financially (JS $=63.1 \% ; \mathrm{JBM}=67.2 \%$ ). The median age of the mothers $(\mathrm{JS}=26 ; \mathrm{JBM}=27)$, care-givers $(\mathrm{JS}=27 ; \mathrm{JBM}=27)$ and fathers $(\mathrm{JS}=30 ; \mathrm{JBM}=32$ ) in the two areas was similar. The median school standard passed by the mothers and fathers, as well as the care-givers, was similar in the two groups and indicated that most had completed primary school education.

The respondents indicated that milk, bread and sweets were mainly bought at the nearest café or tuck shop because they are considered more accessible, while fruit and vegetables were mostly bought from vendors because they were cheaper and also more accessible. Meat was mostly bought at a butchers because it was considered cheaper and more accessible, while groceries were mostly bought at a supermarket in Bloemfontein where it was cheaper. Vegetable gardens or self-produced foodstuffs were seldomly mentioned as a source of food.

\section{Dietary intake}

Breast-feeding practice was only analysed if the mother was the care-giver, since other care-givers could not give accurate information on previous breast-feeding. Breastfeeding practice for the purpose of this study refers to the period the child received breast-feeding, with or without additional foods. In this study population a small number of children (younger than 6 months of age) received exclusive breast-feeding (breast-feeding alone without any additional foods or other milk) (JS=4; JBM $=2$ ). Thus, using survival analysis, it was found that the majority of children were still breast-fed at 12 months (JS = 57.1\%; $\mathrm{JBM}=71 \%$ ) and 18 months of age (JS $=51.3 \%$; JBM $=$ $63.7 \%$ ) (Table 1a). At the time of the study more than half of the children younger than 2 years received breastfeeding (Table 1b).

Due to the high percentage of breast-fed children in the age groups younger than 2 years, the nutrient intake for these age groups are not indicated. The mean (SD) and

Table 1a Percentage of children breast-fed ${ }^{*}$ by age amongst children in two informal settlement areas in Mangaung

\begin{tabular}{lcc}
\hline & $\begin{array}{c}\text { Joe Slovo }(n=80) \\
(\%)\end{array}$ & $\begin{array}{c}\text { JB Mafora }(n=115) \\
(\%)\end{array}$ \\
\hline 1 month & 90.0 & 92.2 \\
3 months & 81.1 & 87.7 \\
6 months & 68.5 & 80.1 \\
9 months & 62.3 & 75.2 \\
12 months & 57.1 & 71.0 \\
15 months & 53.5 & 68.7 \\
18 months & 51.3 & 63.7 \\
21 months & 44.1 & 52.5 \\
24 months & 24.8 & 28.7 \\
28 months & 21.2 & 21.9 \\
36 months & 14.2 & 5.1 \\
\hline
\end{tabular}

${ }^{*}$ Breast-feeding refers to the period the child received breast-feeding with or without additional food or other milk.

Table 1b Number of children breast-fed ${ }^{*}$ at the time of the study amongst children in two informal settlement areas in Manguang

\begin{tabular}{lcccccccc}
\hline & \multicolumn{3}{c}{ Joe Slovo } & & \multicolumn{3}{c}{ JB Mafora } \\
\cline { 2 - 4 } \cline { 7 - 8 } & $n$ & Frequency & $\%$ & & $n$ & Frequency & $\%$ \\
\hline$<1$ year old & 24 & 16 & 67 & & 23 & 17 & 74 \\
$1-1.9$ year old & 28 & 15 & 53.6 & & 41 & & 22 & 54 \\
$2-2.9$ year old & 28 & 2 & 7.1 & & 27 & 3 & 11.1 \\
$3-3.9$ year old & 35 & 5 & 14.3 & & 41 & & 2 & 4.9 \\
$4-4.9$ year old & 31 & 0 & 0 & & 34 & & 0 & 0 \\
$5-5.9$ year old & 16 & 1 & 6.3 & & 21 & & 0 & 0 \\
\hline
\end{tabular}

${ }^{\star}$ Breast-feeding refers to the period the child received breast-feeding with or without additional food or other milk. 
median nutrient intakes (excluding breast milk) are shown in Table 2. Although the median total protein intake (from foods other than breast milk) of most children of 2 years and older were higher than the RDAs, the median energy intake of the children was lower than the RDAs. The median intake of most micronutrients from foods other than breast milk in both areas was lower than the RDAs including iron, zinc, calcium, vitamin $\mathrm{C}$, niacin, thiamine, riboflavin, vitamin $\mathrm{B}_{6}$ and vitamin $\mathrm{A}$ and $\mathrm{D}$. The omega-3 series fatty acid intake was also low.

Table 2 Nutrient intake of preschool children (24-71 months) in two informal settlement areas in Mangaung

\begin{tabular}{|c|c|c|c|c|c|c|c|}
\hline \multirow[b]{2}{*}{ Age category and nutrient } & \multirow[b]{2}{*}{ RDA } & \multicolumn{3}{|c|}{ Joe Slovo } & \multicolumn{3}{|c|}{ JB Mafora } \\
\hline & & Mean & SD & Median & Mean & SD & Median \\
\hline \multicolumn{8}{|l|}{ 2-3.9 year olds* } \\
\hline Energy (kJ) & 5460 & 3424 & 1490 & 3245 & 4274 & 1652 & 3994 \\
\hline Total protein (g) & 16 & 29.6 & 14.6 & 26.5 & 34.1 & 15.4 & 31.8 \\
\hline Plant protein (g) & & 13.9 & 8.2 & 11.9 & 16.8 & 8.2 & 15.7 \\
\hline Animal protein (g) & & 16.0 & 12.3 & 11.9 & 17.3 & 12.6 & 16.5 \\
\hline Total carbohydrate (g) & & 123.8 & 64.7 & 104.2 & 158.6 & 61.2 & 159.3 \\
\hline Added sugar $(\mathrm{g})$ & & 15.5 & 16.5 & 10.0 & 15.3 & 11.6 & 14.6 \\
\hline Dietary fibre $(\mathrm{g})$ & & 7.7 & 4.8 & 5.9 & 9.0 & 4.5 & 8.0 \\
\hline Total fat $(\mathrm{g})$ & & 24.0 & 12.2 & 23.7 & 29.5 & 19.1 & 15.3 \\
\hline SFA $(\mathrm{g})$ & & 8.7 & 5.0 & 8.2 & 9.9 & 6.7 & 8.0 \\
\hline PUFA (g) & & 5.4 & 4.2 & 4.2 & 7.8 & 7.1 & 5.9 \\
\hline Calcium (mg) & 800 & 328.2 & 206.6 & 318.4 & 340.0 & 256.2 & 373.5 \\
\hline Magnesium (mg) & 80 & 154.1 & 78.0 & 141.3 & 196.9 & 94.4 & 193.7 \\
\hline Phosphorus(mg) & 800 & 530.8 & 261.2 & 511.8 & 648.4 & 304.7 & 609.5 \\
\hline Iron (mg) & 10 & 3.6 & 2.2 & 3.6 & 4.5 & 2.6 & 4.1 \\
\hline Zinc (mg) & 10 & 3.9 & 2.4 & 3.6 & 4.2 & 2.2 & 3.9 \\
\hline Vitamin C (mg) & 40 & 13.6 & 27.6 & 5.8 & 17.9 & 22.11 & 12.6 \\
\hline Thiamine (mg) & 0.7 & 0.51 & 0.25 & 0.46 & 0.69 & 0.47 & 0.65 \\
\hline Riboflavin (mg) & 0.8 & 0.59 & 0.33 & 0.55 & 0.73 & 0.42 & 0.64 \\
\hline Niacin (mg) & 9 & 4.9 & 3.4 & 4.5 & 5.3 & 3.4 & 4.8 \\
\hline Vitamin $B_{6}(\mathrm{mg})$ & 1.0 & 0.45 & 0.28 & 0.39 & 0.58 & 0.36 & 0.50 \\
\hline Folic acid $(\mu \mathrm{g})$ & 50 & 80.1 & 45.6 & 81.3 & 105.7 & 67.9 & 90.0 \\
\hline Vitamin $\mathrm{B}_{12}(\mu \mathrm{g})$ & 0.7 & 1.8 & 3.1 & 1.1 & 2.6 & 4.9 & 1.24 \\
\hline Vitamin A (RE) & 400 & 254.3 & 424.2 & 120.1 & 426.3 & 542.8 & 273.2 \\
\hline Vitamin $\mathrm{D}(\mu \mathrm{g})$ & 10 & 0.65 & 2.2 & 0.11 & 1.5 & 2.4 & 0.33 \\
\hline \multicolumn{8}{|l|}{ EFA } \\
\hline omega- 6 series $\left(\mathrm{g} \mathrm{day}^{-1}\right)$ & 4.0 & 5.0 & 4.2 & 3.7 & 7.4 & 7.2 & 2.9 \\
\hline omega-3 series $\left(\mathrm{g} \mathrm{day}^{-1}\right)$ & 0.7 & 0.4 & 0.6 & 0.3 & 0.4 & 0.4 & 0.2 \\
\hline \multicolumn{8}{|l|}{ 4-5.9 year oldst } \\
\hline Energy $(\mathrm{kJ})$ & 7560 & 3780 & 1612 & 3534 & 4383 & 1561 & 4183 \\
\hline Total protein $(\mathrm{g})$ & 24 & 31.7 & 16.1 & 31.4 & 33.9 & 15.4 & 31.1 \\
\hline Plant protein $(\mathrm{g})$ & & 15.0 & 8.1 & 14.1 & 18.0 & 7.0 & 17.3 \\
\hline Animal protein $(\mathrm{g})$ & & 16.7 & 12.8 & 16.4 & 15.9 & 12.4 & 13.0 \\
\hline Total carbohydrate (g) & & 140.1 & 58.6 & 130.1 & 169.7 & 55.1 & 169.3 \\
\hline Added sugar $(\mathrm{g})$ & & 14.4 & 11.9 & 12.2 & 14.0 & 13.1 & 11.2 \\
\hline Dietary fibre (g) & & 8.8 & 5.3 & 7.9 & 9.6 & 4.2 & 8.5 \\
\hline Total fat $(\mathrm{g})$ & & 25.4 & 18.1 & 22.5 & 27.7 & 17.3 & 24.0 \\
\hline SFA $(g)$ & & 9.0 & 5.4 & 8.6 & 9.2 & 5.8 & 8.9 \\
\hline PUFA (g) & & 6.5 & 7.2 & 4.1 & 7.1 & 5.6 & 5.8 \\
\hline Calcium (mg) & 800 & 380.5 & 238.4 & 328.4 & 340.3 & 215.6 & 349.6 \\
\hline Magnesium (mg) & 120 & 178.6 & 82.2 & 171.4 & 202.3 & 71.1 & 202.9 \\
\hline Phosphorus(mg) & 800 & 592.2 & 279.3 & 601.4 & 625.5 & 255.9 & 609.0 \\
\hline Iron (mg) & 10 & 4.0 & 3.1 & 3.3 & 4.6 & 2.4 & 4.0 \\
\hline Zinc (mg) & 10 & 4.3 & 2.4 & 3.8 & 4.4 & 2.5 & 3.6 \\
\hline Vitamin C (mg) & 45 & 17.9 & 23.5 & 9.6 & 14.7 & 11.9 & 11.9 \\
\hline Thiamine (mg) & 0.9 & 0.58 & 0.26 & 0.56 & 0.71 & 0.25 & 0.68 \\
\hline Riboflavin (mg) & 1.1 & 0.71 & 0.41 & 0.66 & 0.67 & 0.39 & 0.61 \\
\hline Niacin (mg) & 12 & 5.6 & 4.4 & 5.0 & 5.7 & 3.3 & 5.0 \\
\hline Vitamin $B_{6}(\mathrm{mg})$ & 1.1 & 0.54 & 0.37 & 0.43 & 0.59 & 0.33 & 0.52 \\
\hline Folic acid $(\mu \mathrm{g})$ & 75 & 103.9 & 70.2 & 92.0 & 108.8 & 54.3 & 97.2 \\
\hline Vitamin $\mathrm{B}_{12}(\mu \mathrm{g})$ & 1.0 & 1.8 & 1.6 & 1.4 & 2.4 & 5.3 & 1.0 \\
\hline Vitamin A (RE) & 500 & 298.4 & 279.7 & 197.5 & 446.2 & 532.6 & 347.7 \\
\hline Vitamin $\mathrm{D}(\mu \mathrm{g})^{\prime}$ & 10 & 1.0 & 2.2 & 0.15 & 0.9 & 1.6 & 0.24 \\
\hline \multicolumn{8}{|l|}{ EFA } \\
\hline omega- 6 series $\left(\mathrm{g} \mathrm{day}^{-1}\right)$ & 6 & 6.2 & 7.3 & 3.8 & 6.7 & 5.6 & 5.4 \\
\hline omega-3 series $\left(\mathrm{g} \mathrm{day}^{-1}\right)$ & 1 & 0.3 & 0.3 & 0.2 & 0.3 & 0.3 & 0.3 \\
\hline
\end{tabular}

EFA, essential fatty acids (Canadian recommendation ${ }^{16}$ ); PUFA, polyunsaturated fatty acids; RDA, recommended dietary allowance (United States recommendation $\left.{ }^{15}\right)$; SFA, saturated fatty acids.

*JS, $n=63 ; \mathrm{JBM}, n=68$.

†JS, $n=46$; JBM, $n=54$. 
The median frequency of foods eaten daily revealed that the diets of the children in both areas consisted mainly of maize-meal porridge, eaten three times a day, followed by milk taken once or twice daily, vegetables and/or fruit once or twice daily, tea or coffee once daily and food from the meat, poultry, fish, eggs and legumes group once daily or less often in the 4 year olds in JS and the 5 year olds in JBM. Sugar and snacks, including sweets, cold drinks, potato crisps, pudding, cakes and biscuits were eaten once daily by most of the children.

\section{Antbropometry}

The percentage of children classified in the different anthropometric categories according to the Z-score is shown in Table 3. The two groups showed similar total distribution amongst the Z-score categories for being underweight, indicating acute malnutrition (W/A $<-2 \mathrm{SD}$ ) (JS $=19.8 \% ; \mathrm{JBM}=18.6 \%)$. Stunting $(\mathrm{H} / \mathrm{A}<-2 \mathrm{SD})$, indicating chronic malnutrition, prevailed more in JS (29.0\%) than in JBM (21.5\%). A slightly higher prevalence of wasted (W/H $<-2 \mathrm{SD})$ children was found in JBM (6.5\%) than in JS (3.7\%). The peak age of wasting in JBM was between 1 and 1.9 years of age (17.1\%), which compares with figures of the $\mathrm{WHO}^{19,26}$ indicating $12-24$ months as the peak age of wasting.

Table 4 illustrates the percentage of children in the NCHS percentile categories for MUAC, TS, UAFA, UAMA and HC. The prevalence of low MUAC values $(<5$ th NCHS percentile) were fairly similar in the two areas (JS $=14.6 \%$; $\mathrm{JBM}=12.3 \%)$. Low TS values were more prevalent in JBM (9.0\%) than in JS (6.3\%). The prevalence of low UAMA (JS $=8.1 \% ; \mathrm{JBM}=6.6 \%)$ and UAFA ( JS $=12.6 \% ; \mathrm{JBM}=11.6 \%)$ values were nearly similar in the two areas. Low MUAC, TS, UAMA and UAFA values were more prominent amongst the 5 year olds in both areas. Low HC values were more prominent in JBM (36.6\%) than in JS (24.4\%).

Very few of the children were overweight or had excessive values for any of the anthropometric measurements.

\section{Biochemical values}

The median plasma vitamin A concentrations were within the adequate range, while the median plasma albumin, transferrin and ferritin concentrations, as well as the median haemoglobin, MCV and haematocrit values were within the normal reference ranges. The percentage of children with plasma values below the normal reference ranges ${ }^{5,22}$ are shown in Table 5 . Low retinol values $\left(<20 \mu \mathrm{g} \mathrm{dl}^{-1}\right)$ were found in $16.7 \%$ (JS) and $20.8 \%$ (JBM) of the children. Of these children very few had biochemical vitamin A deficiency $\left(<10 \mu \mathrm{g} \mathrm{dl}^{-1}\right) \quad(\mathrm{JS}=2.7 \%$; JBM $=1.3 \%)$ or vitamin A concentrations higher than $50 \mu \mathrm{g} \mathrm{dl}^{-1} \quad(\mathrm{JS}=1.3 \%$; $\mathrm{JBM}=0 \%$ ).

Low plasma transferrin and low plasma albumin

Table 3 Percentage of preschool children in different anthropometric categories according to the Z-scores in two informal settlement areas in Mangaung

\begin{tabular}{|c|c|c|c|c|c|c|c|c|c|c|c|c|c|c|c|c|c|c|}
\hline \multirow[b]{3}{*}{ Variables and age groups } & \multicolumn{9}{|c|}{ Joe Slovo } & \multicolumn{9}{|c|}{ JB Mafora } \\
\hline & \multicolumn{2}{|c|}{$<-2 \mathrm{SD}$} & \multicolumn{2}{|c|}{$\begin{array}{c}-2 \text { to } \\
<-1 \text { SD }\end{array}$} & \multicolumn{2}{|c|}{-1 to $2 \mathrm{SD}$} & \multicolumn{2}{|c|}{$>2 \mathrm{SD}$} & \multirow{2}{*}{$\begin{array}{c}\text { Total } \\
n\end{array}$} & \multicolumn{2}{|c|}{$<-2$ SD } & \multicolumn{2}{|c|}{$\begin{array}{c}-2 \text { to } \\
<-1 \text { SD }\end{array}$} & \multicolumn{2}{|c|}{$\begin{array}{l}-1 \text { to } \\
2 \text { SD }\end{array}$} & \multicolumn{2}{|c|}{$>2 \mathrm{SD}$} & \multirow{2}{*}{$\begin{array}{c}\text { Tota } \\
n\end{array}$} \\
\hline & $n$ & $\%$ & $n$ & $\%$ & $n$ & $\%$ & $n$ & $\%$ & & $n$ & $\%$ & $n$ & $\%$ & $n$ & $\%$ & $n$ & $\%$ & \\
\hline \multicolumn{19}{|l|}{ Weight/age } \\
\hline$<1$ year & 5 & 20.8 & 4 & 16.7 & 15 & 62.5 & 0 & 0 & 24 & 4 & 17.4 & 7 & 30.4 & 12 & 52.2 & 0 & 0 & 23 \\
\hline $1-1.9$ years & 4 & 14.8 & 8 & 29.6 & 15 & 55.6 & 0 & 0 & 27 & 9 & 22.0 & 17 & 41.5 & 14 & 34.2 & 1 & 2.4 & 41 \\
\hline $2-2.9$ years & 7 & 25.0 & 8 & 28.6 & 13 & 46.4 & 0 & 0 & 28 & 3 & 11.1 & 6 & 22.2 & 18 & 67.7 & 0 & 0 & 27 \\
\hline $3-3.9$ years & 6 & 17.1 & 16 & 45.7 & 13 & 37.1 & 0 & 0 & 35 & 3 & 7.5 & 14 & 35.0 & 22 & 55.0 & 1 & 2.5 & 40 \\
\hline $4-4.9$ years & 6 & 18.8 & 15 & 46.9 & 11 & 34.4 & 0 & 0 & 32 & 10 & 29.4 & 14 & 41.2 & 10 & 29.4 & 0 & 0 & 34 \\
\hline $5-5.9$ years & 4 & 25.0 & 7 & 43.8 & 5 & 31.3 & 0 & 0 & 16 & 6 & 28.6 & 9 & 42.9 & 6 & 28.6 & 0 & 0 & 21 \\
\hline Total & 32 & 19.8 & 58 & 35.8 & 72 & 44.4 & 0 & 0 & 162 & 35 & 18.6 & 67 & 36.0 & 82 & 44.1 & 2 & 1.1 & 186 \\
\hline \multicolumn{19}{|l|}{ Height/age } \\
\hline$<1$ year & 6 & 25.0 & 5 & 20.8 & 13 & 54.2 & 0 & 0 & 24 & 4 & 17.4 & 5 & 21.7 & 13 & 56.5 & 1 & 4.4 & 23 \\
\hline $1-1.9$ years & 7 & 25.9 & 9 & 33.3 & 11 & 40.7 & 0 & 0 & 27 & 6 & 14.6 & 11 & 26.8 & 23 & 56.1 & 1 & 2.4 & 41 \\
\hline $2-2.9$ years & 11 & 39.3 & 10 & 35.7 & 6 & 21.4 & 1 & 3.6 & 28 & 2 & 7.4 & 8 & 29.6 & 15 & 55.6 & 2 & 7.4 & 27 \\
\hline $3-3.9$ years & 9 & 25.7 & 15 & 42.9 & 10 & 28.6 & 1 & 2.9 & 35 & 8 & 20.0 & 11 & 27.5 & 19 & 47.5 & 2 & 5.0 & 40 \\
\hline $4-4.9$ years & 11 & 34.4 & 9 & 28.1 & 12 & 37.5 & 0 & 0 & 32 & 14 & 41.2 & 9 & 26.5 & 11 & 32.4 & 0 & 0 & 34 \\
\hline $5-5.9$ years & 3 & 18.8 & 8 & 50.0 & 5 & 31.3 & 0 & 0 & 16 & 6 & 28.6 & 8 & 38.1 & 7 & 33.3 & 0 & 0 & 21 \\
\hline Total & 47 & 29.0 & 56 & 34.6 & 57 & 35.2 & 2 & 1.2 & 162 & 40 & 21.5 & 52 & 28.0 & 87 & 47.3 & 6 & 3.2 & 186 \\
\hline \multicolumn{19}{|l|}{ Weight/height } \\
\hline$<1$ year & 0 & 0 & 2 & 8.3 & 22 & 91.7 & 0 & 0 & 24 & 1 & 4.4 & 6 & 26.1 & 13 & 56.5 & 3 & 13.0 & 23 \\
\hline $1-1.9$ years & 1 & 3.7 & 4 & 14.8 & 22 & 81.5 & 0 & 0 & 27 & 7 & 17.1 & 13 & 31.7 & 20 & 48.8 & 1 & 2.4 & 41 \\
\hline $2-2.9$ years & 1 & 3.6 & 4 & 14.3 & 23 & 82.1 & 0 & 0 & 28 & 1 & 3.7 & 3 & 11.1 & 22 & 81.5 & 1 & 3.7 & 27 \\
\hline $3-3.9$ years & 2 & 5.7 & 8 & 22.9 & 25 & 71.4 & 0 & 0 & 35 & 0 & 0 & 5 & 12.5 & 35 & 87.5 & 0 & 0 & 40 \\
\hline $4-4.9$ years & 1 & 3.1 & 6 & 18.8 & 25 & 78.1 & 0 & 0 & 32 & 1 & 2.9 & 11 & 32.4 & 22 & 64.7 & 0 & 0 & 34 \\
\hline $5-5.9$ years & 1 & 6.3 & 7 & 43.8 & 8 & 50.0 & 0 & 0 & 16 & 2 & 9.5 & 4 & 19.1 & 15 & 71.4 & 0 & 0 & 21 \\
\hline Total & 6 & 3.7 & 31 & 19.1 & 125 & 77.2 & 0 & 0 & 162 & 12 & 6.5 & 42 & 22.6 & 127 & 68.3 & 5 & 2.7 & 186 \\
\hline
\end{tabular}


Table 4 Percentage of preschool children in different MUAC, TS, UAMA, UAFA and HC NCHS percentiles categories in two informal settlement areas in Mangaung

\begin{tabular}{|c|c|c|c|c|c|c|c|c|c|c|c|c|c|c|c|c|c|c|}
\hline \multirow[b]{3}{*}{ Variables and age groups } & \multicolumn{9}{|c|}{ Joe Slovo } & \multicolumn{9}{|c|}{ JB Mafora } \\
\hline & \multicolumn{2}{|c|}{$<5$} & \multicolumn{2}{|c|}{5 to $<15$} & \multicolumn{2}{|c|}{15 to $<95^{\star}$} & \multicolumn{2}{|c|}{$\geqslant 95 \dagger$} & \multirow{2}{*}{$\begin{array}{c}\text { Total } \\
n\end{array}$} & \multicolumn{2}{|c|}{$<5$} & \multicolumn{2}{|c|}{5 to $<15$} & \multicolumn{2}{|c|}{15 to $<95^{\star}$} & \multicolumn{2}{|c|}{$\geqslant 95 \dagger$} & \multirow{2}{*}{$\begin{array}{c}\text { Total } \\
n\end{array}$} \\
\hline & $n$ & $\%$ & $n$ & $\%$ & $n$ & $\%$ & $n$ & $\%$ & & $n$ & $\%$ & $n$ & $\%$ & $n$ & $\%$ & $n$ & $\%$ & \\
\hline \multicolumn{19}{|l|}{$\begin{array}{l}\text { Mid upper arm } \\
\text { circumference (MUAC) }\end{array}$} \\
\hline $1-1.9$ years & 1 & 3.9 & 7 & 26.9 & 18 & 69.2 & 0 & 0 & 26 & 7 & 17.1 & 8 & 19.5 & 26 & 63.5 & 0 & 0 & 41 \\
\hline $2-2.9$ years & 4 & 14.3 & 6 & 21.4 & 8 & 64.3 & 0 & 0 & 28 & 2 & 7.4 & 2 & 7.4 & 22 & 81.5 & 1 & 3.7 & 27 \\
\hline $3-3.9$ years & 5 & 14.3 & 2 & 5.7 & 2 & 80.0 & 0 & 0 & 35 & 1 & 2.5 & 2 & 5.0 & 36 & 90.0 & 1 & 2.5 & 40 \\
\hline $4-4.9$ years & 3 & 9.4 & 7 & 21.9 & 22 & 68.8 & 0 & 0 & 32 & 4 & 11.8 & 10 & 29.4 & 20 & 58.8 & 0 & 0 & 34 \\
\hline $5-5.9$ years & 7 & 43.8 & 6 & 37.5 & 3 & 18.8 & 0 & 0 & 16 & 6 & 28.6 & 4 & 19.1 & 11 & 52.4 & 0 & 0 & 21 \\
\hline Total & 20 & 14.6 & 28 & 20.4 & 89 & 65.0 & 0 & 0 & 137 & 20 & 12.3 & 26 & 16.0 & 115 & 70.6 & 2 & 1.2 & 163 \\
\hline \multicolumn{19}{|l|}{ Triceps skinfold (TS) } \\
\hline $2-2.9$ years & 0 & 0.0 & 3 & 10.7 & 2 & 85.7 & 1 & 3.6 & 28 & 1 & 3.9 & 1 & 3.9 & 24 & 92.4 & 0 & 0 & 26 \\
\hline $3-3.9$ years & 1 & 2.9 & 7 & 20.0 & 27 & 77.2 & 0 & 0 & 35 & 1 & 2.5 & 9 & 22.5 & 30 & 75.0 & 0 & 0 & 40 \\
\hline $4-4.9$ years & 3 & 9.4 & 9 & 28.1 & 20 & 62.5 & 0 & 0 & 32 & 5 & 14.7 & 13 & 38.2 & 16 & 47.0 & 0 & 0 & 34 \\
\hline $5-5.9$ years & 3 & 18.8 & 6 & 37.5 & 7 & 43.8 & 0 & 0 & 16 & 4 & 19.1 & 6 & 28.6 & 11 & 52.4 & 0 & 0 & 21 \\
\hline Total & 7 & 6.3 & 25 & 22.5 & 78 & 57.0 & 1 & 0.9 & 111 & 11 & 9.0 & 29 & 24.0 & 81 & 66.9 & 0 & 0 & 121 \\
\hline \multicolumn{19}{|l|}{$\begin{array}{l}\text { Upper arm muscle } \\
\text { area (UAMA) }\end{array}$} \\
\hline $2-2.9$ years & 3 & 10.7 & 1 & 3.6 & 22 & 78.6 & 2 & 7.1 & 28 & 2 & 7.7 & 0 & 0.0 & 20 & 76.9 & 4 & 15.4 & 26 \\
\hline $3-3.9$ years & 2 & 5.7 & 2 & 5.7 & 29 & 82.9 & 2 & 5.7 & 35 & 2 & 5.0 & 2 & 5.0 & 30 & 75.0 & 6 & 15.0 & 40 \\
\hline $4-4.9$ years & 1 & 3.1 & 4 & 12.5 & 24 & 75.0 & 3 & 9.4 & 32 & 2 & 5.9 & 3 & 8.8 & 27 & 79.4 & 2 & 5.9 & 34 \\
\hline $5-5.9$ years & 3 & 18.8 & 4 & 25.0 & 8 & 50.0 & 1 & 6.3 & 16 & 2 & 9.5 & 6 & 28.6 & 13 & 61.9 & 0 & 0.0 & 21 \\
\hline Total & 9 & 8.1 & 11 & 9.9 & 83 & 74.8 & 8 & 7.2 & 111 & 8 & 6.6 & 11 & 9.1 & 90 & 74.4 & 12 & 9.9 & 121 \\
\hline \multicolumn{19}{|l|}{$\begin{array}{l}\text { Upper arm fat area } \\
\text { (UAFA) }\end{array}$} \\
\hline $2-2.9$ years & 1 & 3.6 & 5 & 17.9 & 20 & 71.4 & 2 & 7.1 & 28 & 2 & 7.7 & 1 & 3.9 & 21 & 80.8 & 2 & 7.7 & 26 \\
\hline $3-3.9$ years & 4 & 11.4 & 9 & 25.7 & 21 & 60.0 & 1 & 2.9 & 35 & 1 & 4.9 & 9 & 22.0 & 30 & 73.2 & 0 & 0.0 & 40 \\
\hline $4-4.9$ years & 4 & 12.5 & 8 & 25.0 & 20 & 62.5 & 0 & 0.0 & 32 & 5 & 15.2 & 1 & 30.3 & 18 & 54.2 & 0 & 0.0 & 34 \\
\hline $5-5.9$ years & 5 & 31.3 & 9 & 56.3 & 2 & 12.6 & 0 & 0.0 & 16 & 5 & 23.8 & 8 & 38.1 & 8 & 38.1 & 0 & 0.0 & 21 \\
\hline Total & 14 & 12.6 & 31 & 27.9 & 63 & 56.8 & 3 & 2.7 & 111 & 14 & 11.6 & 8 & 23.1 & 77 & 63.6 & 2 & 1.7 & 121 \\
\hline \multicolumn{19}{|l|}{ Head circumference $(H C)$} \\
\hline$<1$ year & 6 & 25.0 & & & 17 & 70.8 & 1 & 4.2 & 24 & 8 & 34.8 & & & 14 & 60.9 & 1 & 4.4 & 23 \\
\hline $1-1.9$ years & 5 & 18.5 & & & 18 & 70.4 & 3 & 11.1 & 27 & 17 & 41.5 & & & 23 & 56.1 & 1 & 2.4 & 41 \\
\hline $2-2.9$ years & 8 & 29.6 & & & 19 & 66.7 & 1 & 3.7 & 27 & 8 & 29.6 & & & 19 & 70.4 & 0 & 0 & 27 \\
\hline Total & 19 & 24.4 & & & 54 & 69.2 & 5 & 6.4 & 78 & 33 & 36.3 & & & 56 & 61.5 & 2 & 2.2 & 91 \\
\hline
\end{tabular}

${ }^{*} \mathrm{NCHS}$ percentile category for UAFA is 15 to $<85$.

$\dagger$ NCHS percentile category for UAFA is $\geqslant 85$.

concentrations prevailed in a small number of children $(\mathrm{JS}=6.9 \% ; \mathrm{JBM}=6.7 \%$ and $\mathrm{JS}=4.0 \% ; \mathrm{JBM}=3.7 \%$, respectively) (Table 5). The overall prevalence of depleted iron stores was fairly similar in the two groups (JS $=19.3 \%$; $\mathrm{JBM}=17.3 \%)$. According to the SAVACG ${ }^{5}$ cut-off values, a large percentage of children showed low haemoglobin $(\mathrm{JS}=43.7 \% ; \mathrm{JBM}=47.8 \%)$ and low $\mathrm{MCV}(\mathrm{JS}=12 \% ; \mathrm{JBM}=$ $15.2 \%$ ) values (Table 5 ). When age-specific cut-off values were used $^{22}$, fewer children had low haemoglobin (JS = $9.5 \% ; \mathrm{JBM}=10.1 \%)$ and $\mathrm{MCV}(\mathrm{JS}=8.2 \% ; \mathrm{JBM}=10.7 \%)$ values.

The prevalence of low values for both haemoglobin and plasma ferritin were slightly higher in JS (16.2\%) than in JBM (12.8\%). Iron deficiency anaemia $\left(\mathrm{Hb}<11 \mathrm{~g} \mathrm{dl}^{-1}+\right.$ plasma ferritin $<12 \mu \mathrm{g} \mathrm{dl}^{-1}+\mathrm{MCV}<$ normal for age ${ }^{5}$ ) prevailed in a small number of the children in both groups $(\mathrm{JS}=6.8 \% ; \mathrm{JBM}=5.4 \%)$, and was more prevalent in children of 2 years and younger in both areas.
The most prominent parasites found in the stools of the children were cysts of Giardia lamblia (JS $=24.5 \%$; $\mathrm{JBM}=24.7 \%$ ).

Due to the small number of well-nourished children $(\mathrm{W} / \mathrm{A}>0 \mathrm{SD}$ and $\mathrm{H} / \mathrm{A}>0 \mathrm{SD})(\mathrm{JS}=9.9 \% ; \mathrm{JBM}=9.1 \%)$ and the generally poor household resource situation of the participants, no significant associations could be found between household and nutritional status indicators. However, the well-nourished children tended to have a better household background.

\section{Discussion}

The study describes and compares the nutritional status and household resources in two informal settlement areas, in an attempt to identify issues that should be addressed in a nutrition intervention programme. The results indicate that the number of well-nourished children were small 


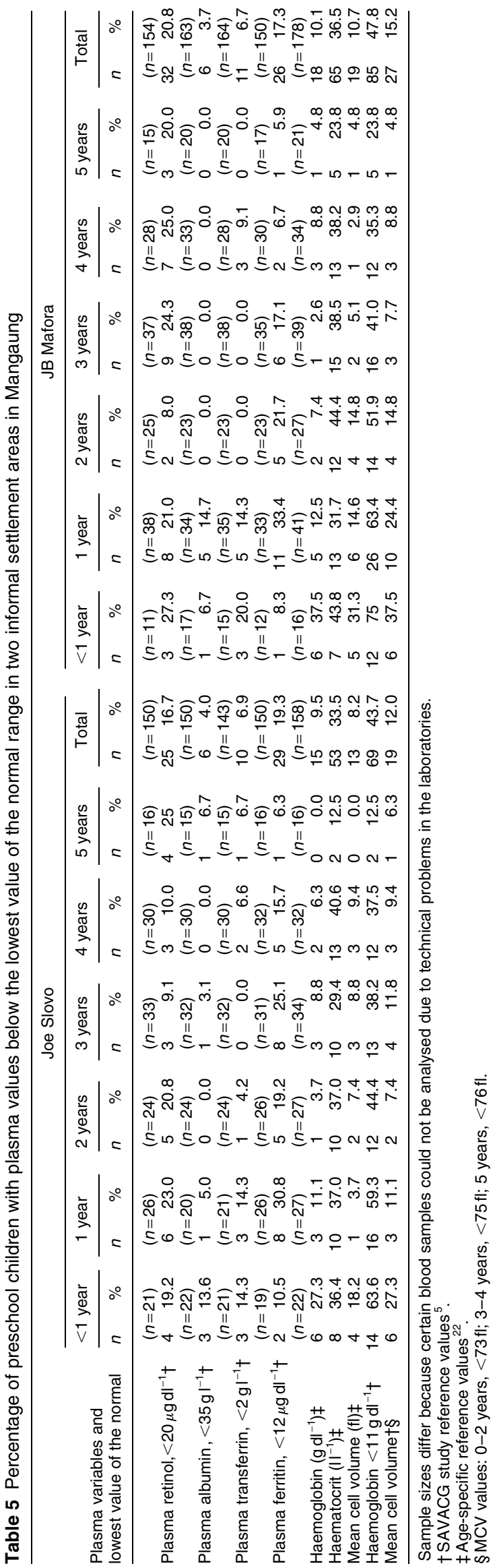

and that similar profiles of poor household resources prevailed in both areas.

It is well accepted that poverty and lack of education are often the effects of underdevelopment and are the primary causes of hunger and undernutrition ${ }^{27}$. Furthermore, poor people in most societies do not have the basic requirements which are necessary for nutritional well-being, which include adequate access to food, safe water and sanitation, health services and education. Although, in this study, no significant associations between nutritional status indicators and household resources were found, the results suggest that poverty and lack of basic resources for nutritional well-being formed the background for the prevalence of undernutrition in both areas.

Breast-feeding is well known to play an important role in the nutritional well-being of infants and is also a traditional method of child feeding in African populations. Inadequate weaning practices are well recognized as an important cause of morbidity and mortality in young children ${ }^{27}$. In the present study more than half of children younger than 24 months were breast-fed at the time of this study, while a relatively high prevalence of being underweight and stunted prevailed in the same age group. Thus, it is most likely, that inadequate dietary intake, including inadequate weaning practices were present in these children. Unfortunately the information about weaning practices gathered in this study were inaccurate and therefore discarded. Sound weaning practices play an essential role in the growth and development of young children and lack of this information is a limitation of this study. It is thus recommended that the weaning practices of these children should be determined comprehensively.

The results also revealed that the median nutrient intake of children of 24 months and older were generally lower than the RDAs. The low energy intake, was reflected in the anthropometric indicators of the children. Although wasting peaked in the 1 year olds in JBM, the three forms of undernutrition were spread fairly constantly across the age groups in both areas, which indicate that acute and chronic malnutrition prevailed in both areas.

According to the classification of the WHO global database $^{6}$, the prevalence of being underweight and stunted found in JS and JBM can be classified as moderate. This prevalence compares well with figures found in other informal settlement areas in South Africa ${ }^{2,3}$, as well as with the overall national South African figure ${ }^{4,5}$.

Low MUAC values are generally associated with a specific and relative risk for malnutrition and are widely used as an indicator of thinness ${ }^{19}$. The prevalence of low MUAC values were similar in the two areas and also similar to the prevalence of being underweight found in both areas, as well as with the percentage of children with low UAFA and UAMA values. UAFA gives an indication of energy stores in the body, while UAMA gives an indication of lean body mass or skeletal muscle reserves. Low UAFA and UAMA values were more prominent in the older 
children, who also had a low energy intake. The prevalence of depleted MUAC, UAFA and UAMA values showed that together with being underweight and stunted the children also showed low fat and muscle reserves.

The low median dietary intake was also reflected in the laboratory values. Together with a low median iron intake, anaemia $\left(\mathrm{Hb}<11 \mathrm{~g} \mathrm{dl}^{-1}\right)$ was prevalent in a large number of the children (JS $=43.7 \%$; JBM $=47.8 \%$ ), and was higher than the national figure $(21.4 \%)^{5}$. Iron deficiency, however, prevailed in a smaller number $(\mathrm{JS}=19.3 \%$; JBM $=$ $17.3 \%)$, but the prevalence was higher than the national figure $(9.8 \%)^{5}$. Low levels of both haemoglobin and plasma ferritin, as well as low levels for haemoglobin, plasma ferritin and MCV (iron deficiency anaemia) were also higher than the national figure $(5 \%$ and $3.4 \%$, respectively $)^{5}$.

Intestinal parasites may be associated with a reduction in food intake, malabsorption, endogenous nutrient loss and anaemia ${ }^{28}$. Giardia lamblia, the most common parasite discovered in the stools of the children causes malabsorption ${ }^{29}$, which probably can have a negative effect not only on the absorption of nutrients, including iron, but also on the total growth and nutritional wellbeing of the children.

Together with a low median vitamin A intake, inadequate vitamin A status (serum retinol $<20 \mu \mathrm{g} \mathrm{dl}^{-1}$ ) prevailed in $16.7 \%$ to $20.8 \%$ of the children. These figures are lower than the national figure for South African preschool children (33.3\%), as well as for the Free State children $(26.8 \%)^{5}$. According to $\mathrm{WHO}^{30}$ a vitamin A deficiency prevalence of more than $20 \%$ is regarded as high and a prevalence between $10 \%$ and less than $20 \%$ as moderate. In the light of the negative consequences of vitamin $\mathrm{A}$ deficiency on the growth and development of children ${ }^{31}$, the moderate to high prevalence of vitamin A deficiency in the present study is a matter for concern.

Although the median total protein intake was sufficient, the quality was probably low, as suggested by the low median intake of iron, zinc, niacin, riboflavin, calcium, vitamin $\mathrm{A}$ and $\mathrm{B}_{6}$. The low median intake of niacin may also be related to the dependency on maizemeal as a staple food. The low intake of fresh fruit and vegetables was reflected in the children's low median vitamin $\mathrm{C}$ intake. The regular use of moroho, a green leafy vegetable, possibly explains the higher median folic acid intake. The mainly cereal-based diet, together with the low median vitamin $\mathrm{C}$ intake, probably also contributed to a low iron bioavailability ${ }^{32}$ in the present study.

The results indicate that the majority of the children suffered from marginal malnutrition, which was probably due to their low median nutrient intake, together with the poor household resources. When the functional significance of mild to moderate malnutrition is considered ${ }^{33}$, the urgency of addressing these nutrition-related problems is obvious.
A nutrition intervention programme should be based on the findings of this study and should therefore aim to bring about improved nutrition surveillance, together with nutrition education emphasizing sound weaning practices, food selection, food preparation and food production. The availability and affordability of foods should also be increased. It is clear that an intervention programme should be implemented to also bring about community resource development, including job creation, training, improvement in the supply of water, electricity and hygienic toilets. Such a programme should be undertaken by a multidisciplinary team, including the community and various governmental and non-governmental organizations. Moreover, it is recommended that the effect of the nutrition education intervention programme on the nutritional status of the children be evaluated. It must, however, be emphasized that although stunting is regarded as a marker for poverty and deprivation, which can be reduced by improved socioeconomic conditions and better health care facilities, it can not easily be eliminated ${ }^{34}$, as catch-up in height usually takes a relative long time, even in favourable environments ${ }^{18}$. Underweight and wasting, on the other hand, can develop rapidly, but can also be restored rapidly under favourable conditions ${ }^{34}$.

\section{Acknowledgements}

We would like to thank the final year students of the Department of Human Nutrition, personnel of the Department of Paediatrics and Child Health who assisted in the drawing of the blood samples, personnel of the Department of Health and of the Mangaung University Community Partnership Programme, as well as the fieldworkers, the respondents and personnel at the two clinics for their kind assistance.

\section{References}

1 UNICEF. The state of the world's children 1998: a UNICEF report - malnutrition: causes, consequences, and solutions. Nutr. Rev. 1998; 56(4): 115-23.

2 Glatthaar II. Protein-energy malnutrition in South African preschool children. S. Afr. J. of Continuing Medical Education 1992; 10(8): 1329-38.

3 Hugo-Hamman CT, Kibel MA, Michie CA, Yach D. Nutrition status of pre-school children in a Cape Town township. $S$. Afr. Med.J. 1987; 72: 353-5.

4 Nutrition Committee. Draft Report: an Integrated Nutrition Strategy for South Africa. Pretoria: Department of Health, 1994.

5 Labadarios D, Van Middelkoop A, eds. Children aged 6 to 71 months in South Africa, 1994: their Anthropometric, Vitamin A, Iron and Immunisation Coverage Status. Johannesburg: South African Vitamin A Consultative Group (SAVACG), 1994.

6 De Onís M, Monteiro C, Akré J, Clugston G. The worldwide magnitude of protein-energy malnutrition: an overview from the WHO Global Database on Child Growth. Bull. World Health Organ. 1993; 6: 703-12.

7 Williams CD. The story of kwashiorkor. Nutr. Rev. 1973; 31: $334-40$. 
8 UNICEF. A UNICEF Policy Review: Strategy for Improved Nutrition of Children and Women in Developing Countries. New York: United Nations Children's Fund, 1990.

9 Mahan LK, Escott-Stump S. Krause's Food Nutrition and Diet Therapy, 9th edn. Philadelphia: WB Saunders, 1996.

10 Lee RD, Nieman DC. Nutritional Assessment. Oxford: WCB Brown \& Benchmark, 1993

11 Frisancho AR. Anthropometric Standards for the Assessment of Growth and Nutritional Status. Ann Arbor: University of Michigan Press, 1990.

12 Torún B, Chew F. Protein-energy malnutrition. In: Shils ME, Olson JA, Shike M, eds. Modern Nutrition in Health and Disease, 8th edn. Philadelphia: Lea \& Febiger, 1994; 950-76.

13 Langenhoven ML, Conradie PJ, Gouws E, Wolmerans P, Van Eck M. NRIND Food Quantities Manual. Parow: National Research Institute for Nutritional Diseases (NRIND) of the Medical Research Council (MRC), 1986.

14 Langenhoven ML, Kruger M, Gouws E, Faber M. MRC Food Composition Tables (1991), 3rd edn. Parow: National Research Institute for Nutritional Diseases (NRIND) of the Medical Research Council (MRC), 1991.

15 Food and Nutrition Board. Recommended Dietary Allowances, 10th edn. Washington: National Academy Press, 1989.

16 Simopoulos AP. Omega-3 fatty acids in health and disease and in growth and development. Am. J. Clin. Nutr. 1991; 54: 438-63.

17 Jelliffe DB. The Assessment of the Nutritional Status of the Community. Geneva: World Health Organization, 1966.

18 Golden BE. Primary protein-energy malnutrition. In: James JC, Garrow WPT, eds. Human Nutrition and Dietetics, 9th edn. London: Churchill Livingstone, 1993; 441-4.

19 Waterlow JC. Protein Energy Malnutrition. London: Edward Arnold, 1992

20 Nierenberg DW, Nann SL. A method for determining concentrations of retinol, tocopherol and five carotenoids in human plasma and tissue samples. Am. J. Clin. Nutr. 1992; 56(2): 417-26.

21 UNICEF-WHO Joint Committee on Health Policy. Indicators for Assessing Vitamin A Deficiency. Geneva:
World Health Organization, January 1994 (review version, May 1994)

22 Bain BJ. Blood Cells. A Practical Guide, 2nd edn. London Blackwell Science, 1995

23 Frip PJ. An Introduction to Human Parasitology with Reference to Southern Africa. Wynberg: Rustica Press, 1979.

24 Dean AD, Dean JA, Burton JH, Dicker RC. Epi-Info Version 5:O Word Processing, Database, and Epidemiology on Micro Computers. Atlanta, GA: Centers for Disease Control, 1990.

25 SAS Institute Inc. SAS/STAT ${ }^{\circledR}$ User's Guide, Version 6, Vol. 1 4th edn. Cary, NC: SAS Institute Inc., 1989.

26 Keller W, Fillmore CM. Prevalence of protein-energy malnutrition. World Health Stat. Q. 1983; 36: 129-67.

27 WHO. World Declaration on Nutrition - Plan of Action Geneva: World Health Organization, Division of Food and Nutrition, 1992.

28 ACC/SCN (Administrative Committee on Coordination/Subcommittee on Nutrition). Malnutrition and Infection. A Review. London: London School of Hygiene and Tropical Medicine, 1989.

29 Leventhal RL, Cheadle RF. Medical Parasitology. A Self Instructional Text. Philadelphia: FA Davies, 1979.

30 WHO. Global Prevalence of Vitamin A Deficiency. Geneva: World Health Organization, 1995.

31 Stoltzfus R, Klemm R. Report of the XVIII International Vitamin A Consultative Group meeting, 1997. Sustainable Control of Vitamin A Deficiency: Defining progress through assessment, surveillance, evaluation. Washington, DC: ILSI Press, 1998

32 Hallberg L, Sandström B, Agget PJ. Iron, zinc, and other trace elements. In: Garrow JS, James WPT, Ralph A, eds. Human Nutrition and Dietetics, 9th edn. London: Churchill Livingstone, 1993; 174-88.

33 Buzina R, Bates CJ, Van der Beek J, et al. Workshop on functional significance of mild-to-moderate malnutrition. Am. J. Clin. Nutr. 1989; 50: 172-6.

34 Gorstein J, Sullivan K, Yip R, et al. Issues in the assessment of nutritional status using anthropometry. Bull. World Health Organ. 1994; 72(2): 272-83. 